\title{
Description of Two New Thermophilic Desulfotomaculum spp., Desulfotomaculum putei sp. nov., from a Deep Terrestrial Subsurface, and Desulfotomaculum luciae sp. nov., from a Hot Spring
}

YITAI LIU, ${ }^{1}$ TIM M. KARNAUCHOW,${ }^{2} \dagger$ KEN F. JARRELL, ${ }^{2}$ DAVID L. BALKWILL, ${ }^{3}$ GWENDOLYN R. DRAKE, ${ }^{3}$ DAVID RINGELBERG,${ }^{4}$ RONALD CLARNO,${ }^{1}$ AND DAVID R. BOONE ${ }^{1 *}$

Department of Environmental Science and Engineering, Oregon Graduate Institute of Science and Technology, Portland, Oregon 97291-1000'; Department of Microbiology and Immunology, Queen's University, Kingston, Ontario, Canada K7L 3N6 ${ }^{2}$; Department of Biological Science, Florida State University, Tallahassee, Florida 32306 ${ }^{3}$; and Center for Environmental Biotechnology, University of Tennessee, Knoxville, Tennessee 37932-2577

\begin{abstract}
Six strains of thermophilic, endospore-forming, sulfate-reducing bacteria were enriched and isolated from $2.7 \mathrm{~km}$ below the earth's surface in the Taylorsville Triassic Basin in Virginia. The cells of these strains were motile rods that were 1 to $1.1 \mu \mathrm{m}$ in diameter and 2 to $5 \mu \mathrm{m}$ long. The cells grew by oxidizing $\mathrm{H}_{2}$, formate, methanol (weakly), lactate (incompletely, to acetate and $\mathrm{CO}_{2}$ ), or pyruvate (incompletely) while reducing sulfate to sulfide; acetate did not serve as a catabolic substrate. Thiosulfate or sulfite could replace sulfate as an electron acceptor. The results of a phylogenetic analysis of the 16S rRNA gene indicated that these strains belong to the genus Desulfotomaculum, but are distinct from previously described Desulfotomaculum species. Thus, we propose a new species, Desulfotomaculum putei, for them, with strain TH-11 (= SMCC W459) as the type strain. The results of our phylogenetic analysis also indicated that strain SLT $^{\mathrm{T}}$, which was isolated from a hot spring and has been described previously (T. M. Karnauchow, S. F. Koval, and K. F. Jarrell, Syst. Appl. Microbiol. 15:296-310, 1992), is also a member of the genus Desulfotomaculum and is distinct from other species in this genus. We therefore propose the new species Desulfotomaculum luciae for this organism; strain SLT (= SMCC W644) is the type strain of $D$. luciae.
\end{abstract}

Moderately thermophilic sulfate-reducing bacteria are found in a wide range of anaerobic environments, including geothermal regions. The extremely thermophilic sulfate reducers are members of the Archaea; however, the moderately thermophilic sulfate reducers are true bacteria, and all of these bacteria fall in the genera Desulfotomaculum, Thermodesulfobacterium, and Thermodesulfovibrio $(19,20,36)$. The genera Thermodesulfobacterium and Thermodesulfovibrio are genera that contain non-endospore-forming, thermophilic, sulfate-reducing rods. The genus Desulfotomaculum contains endospore-forming sulfate-reducing bacteria, including seven thermophilic species isolated from thermal groundwater and springs and from anaerobic digestors (Table 1). An important role of Desulfotomaculum species in these environments is the oxidation of organic compounds with concomitant reduction of sulfate and other sulfur oxyanions to sulfide.

We describe here two new sulfate-reducing Desulfotomaculum species, including a strain isolated from a geothermal spring (24) and a group of new isolates obtained from a deep terrestrial subsurface environment (6).

(Some of the results of this work have been presented previously [5].)

\section{MATERIALS AND METHODS}

Inoculum for isolation of new strains. Subsurface samples were obtained as part of an experiment to determine whether viable bacteria exist in geological strata that probably have been isolated hydrologically from the surface for more

* Corresponding author. Mailing address: Department of Environmental Science and Engineering, Oregon Graduate Institute of Science and Technology, P.O. Box 91000, Portland, OR 97291-1000. Fax: (503)690-1273. E-mail: boone@ese.ogi.edu.

$\uparrow$ Present address: Department of Microbiology and Immunology, University of Ottawa, Ottawa, Ontario, Canada N6A 5C1. than $10^{8}$ years. Samples were taken laterally from the sidewall of a well (10). The samples, which were obtained from $2.7 \mathrm{~km}$ below the land surface in the Taylorsville Triassic Basin in Virginia, consisted of fine-grained, laminated siltstone (2, $5,6)$. The in situ conditions of the sample site were estimated to be thermal $\left(60^{\circ} \mathrm{C}\right)$, brackish $(1.2 \% \mathrm{NaCl})$, and anoxic (2). The samples were immediately placed in a chamber containing an inert atmosphere, pared to remove the potentially contaminated surface portions, and then shipped on ice to a laboratory within $24 \mathrm{~h}(10)$. The samples were inoculated into enrichment cultures for a variety of bacterial physiological groups, and predominantly anaerobic thermophilic bacteria, including fermentative, iron-reducing, sulfate-reducing, and denitrifying bacteria, grew $(5,6)$. The possibility that the organisms might be the result of contamination during the drilling and sampling process was eliminated by several lines of evidence $(2,5,10)$. Two of the most significant lines of evidence were the finding that some bacteria occurred in very large numbers in the drilling mud yet were not present in detectable numbers in the samples and the finding that when large numbers of microscopic latex beads were added to the drilling mud at the site of sample collection, beads were absent from the pared rock samples.

Sources of cultures. Desulfotomaculum nigrificans Delft $74^{\mathrm{T}}$ (= ATCC 19998 ${ }^{\mathrm{T}}$ ) was obtained from the American Type Culture Collection (Rockville, Md.). The western branch of the DOE Subsurface Microbial Culture Collection (SMCC) (Oregon Graduate Institute, Portland, Oreg.) provided strain $\operatorname{SLT}^{\mathrm{T}}$ (= SMCC $\mathrm{W} 644^{\mathrm{T}}$ ).

Culture methods and media. Strains were cultured by using serum tube modifications of the anaerobic techniques of Hungate (21). Cultures were grown at $55^{\circ} \mathrm{C}$ in modified MS medium. MS medium is an anaerobic medium with a bicarbonate and $\mathrm{CO}_{2}$ buffer system (the headspace gas is $\mathrm{N}_{2}-\mathrm{CO}_{2},[7: 3]$ ) and contains minerals, yeast extract $(2 \mathrm{~g} /$ liter $)$, peptones $(2 \mathrm{~g} / \mathrm{liter})$, and mercaptoethanesulfonate as a reducing agent (4). This medium was modified by flushing it with $\mathrm{N}_{2}$ to raise the $\mathrm{pH}$ to 7.8 , and in order to eliminate precipitates that would otherwise occur at higher $\mathrm{pH}$ values, we further modified the medium by decreasing the concentration of calcium chloride dihydrate to $0.08 \mathrm{~g} /$ liter. This modified medium (MSA medium) was used for routine growth of cells by adding $10 \mathrm{mM}$ sodium sulfate and $20 \mathrm{mM}$ lactate, which served as catabolic substrates. MSA mineral medium was the same as MSA medium except that the organic constituents (peptones, yeast extract, and mercaptoethanesulfonate) were omitted. The medium which was used for enrichment of bacteria from the deep subsurface (which led to the isolation of strains which we refer to as the Thorn Hill strains, including strains TH- $11^{\mathrm{T}}$, TH-12, TH-13, TH-14, TH-15, and TH-16) was medium B (37). Medium B contained (per liter) $3.5 \mathrm{~g}$ of sodium lactate, $2.0 \mathrm{~g}$ of $\mathrm{MgSO}_{4} \cdot 7 \mathrm{H}_{2} \mathrm{O}, 1.0 \mathrm{~g}$ of yeast extract, $1.0 \mathrm{~g}$ of $\mathrm{NH}_{4} \mathrm{Cl}, 1.0 \mathrm{~g}$ of $\mathrm{CaSO}_{4}, 0.5 \mathrm{~g}$ of $\mathrm{KH}_{2} \mathrm{PO}_{4}$, and $0.5 \mathrm{~g}$ of $\mathrm{FeSO}_{4} \cdot 7 \mathrm{H}_{2} \mathrm{O}$. Roll tubes (21) containing medium B 
TABLE 1. Characteristics of some thermophilic Desulfotomaculum species and D. numinis

\begin{tabular}{|c|c|c|c|c|c|c|c|c|c|c|c|}
\hline \multirow[b]{2}{*}{ Staining } & \multirow{2}{*}{$\begin{array}{c}\text { Cell } \\
\text { width } \\
(\mu \mathrm{m})\end{array}$} & \multirow{2}{*}{$\begin{array}{c}\text { Cell } \\
\text { length } \\
(\mu \mathrm{m})\end{array}$} & \multicolumn{2}{|c|}{$\begin{array}{l}\text { Gram } \\
\text { reaction }\end{array}$} & \multirow{2}{*}{ Motility } & \multirow{2}{*}{ Flagella } & \multirow{2}{*}{$\begin{array}{l}\mathrm{G}+\mathrm{C} \\
\text { content } \\
(\mathrm{mol} \%)\end{array}$} & \multirow{2}{*}{$\begin{array}{l}\text { Spore } \\
\text { location }\end{array}$} & \multirow{2}{*}{$\begin{array}{l}\text { Spore } \\
\text { shape }\end{array}$} & \multirow{2}{*}{$\begin{array}{c}\text { Gas } \\
\text { vacuoles }\end{array}$} & \multirow{2}{*}{$\begin{array}{l}\text { Growth } \\
\text { factor(s) } \\
\text { required }\end{array}$} \\
\hline & & & $\begin{array}{c}\text { Stain- } \\
\text { ing }\end{array}$ & $\begin{array}{c}\text { Struc- } \\
\text { ture }\end{array}$ & & & & & & & \\
\hline Strain $\mathrm{TH}-11^{\mathrm{T}}$ & $1-1.1$ & $2-5$ & $--^{b}$ & ND & + & ND & 47.1 & Paracentral & Oval & - & None $^{c}$ \\
\hline Desulfotomaculum nigrificans & $1-1.2^{f}$ & $3-6$ & $\mathrm{v}$ & + & + & Peritrichous & $48.5-49.9$ & Subterminal & Oval & - & Yeast extract \\
\hline Desulfotomaculum ruminis & 0.5 & $3-6$ & - & ND & + & Peritrichous & $48.5-49.9$ & Subterminal & Oval & - & Acetate \\
\hline Strain SLT $^{\mathrm{T}}$ & 1 & 3 & $?^{k}$ & + & + & Peritrichous & 51.4 & Central & Sphere & - & None \\
\hline Desulfotomaculum australicum & $0.8-1$ & $3-6$ & - & + & + & ND & 48.1 & Paracentral & Sphere & - & None \\
\hline Desulfotomaculum thermobenzoicum & $1.5-2$ & $5-8$ & + & + & + & ND & 52.8 & Central & Sphere & ND & Yeast extract \\
\hline Desulfotomaculum geothermicum & 0.5 & $2.3-2.5$ & - & + & + & 2 or more & 50.4 & Subterminal & Sphere & + & None \\
\hline Desulfotomaculum thermoacetoxydans & 0.7 & $2-5$ & - & + & + & ND & 49.7 & Central & Sphere & - & Vitamins \\
\hline Desulfotomaculum thermosapovorans & $1.5-2$ & $5-8$ & ND & ND & + & ND & 51.2 & Paracentral & Sphere & - & Vitamins \\
\hline Desulfotomaculum kuznetsovii & $1-1.4$ & $3.5-5$ & - & + & ND & Peritrichous & 49 & Central & Sphere & - & None \\
\hline Desulfotomaculum thermocisternum & $0.7-1$ & $2-5.2$ & ND & + & + & Peritrichous & $56,57^{n}$ & Central & Sphere & - & Biotin \\
\hline
\end{tabular}

"Species that are able to oxidize butyrate are also able to oxidize many longer saturated carboxylic acids.

$b_{-}$, negative; + , positive; $v$, variable (11 to $89 \%$ of the strains are positive); (w), weak; ND, not determined.

"None means that the organism is able to grow in medium containing $\mathrm{H}_{2}, \mathrm{CO}_{2}$, and sulfate without organic compounds.

${ }^{d}$ All of the Thorn Hill strains grew at $60^{\circ} \mathrm{C}$, and none grew at $70^{\circ} \mathrm{C}$; strains $\mathrm{TH}-11^{\mathrm{T}}$, TH- 12 , and $\mathrm{TH}-16$ did not grow at $65^{\circ} \mathrm{C}$, but the other three strains did.

"Although strain $\mathrm{TH}-11^{\mathrm{T}}$ did not grow at $\mathrm{pH} 6$, the other five Thorn Hill strains did. No pH value below 6.0 was tested.

${ }^{f}$ The previously reported cell width is 0.3 to $0.5 \mu \mathrm{m}(9)$, but by using wet mounts and phase-contrast microscopy, we determined that the cell width is 1 to $1.2 \mu \mathrm{m}$ and the cell length is 3 to $6 \mu \mathrm{m}$.

${ }^{g}$ Formate oxidation has been reported previously (25), although Campbell and Postgate (9) determined that this compound could not be used.

${ }^{h}$ Confirmed in this study.

'Our data indicate that sulfite is not reduced, but previously published data $(11,33)$ indicate that it is.

${ }^{j}$ Determined in this study.

${ }^{k}$ The Gram stain results obtained for the type strain vary.

${ }^{I}$ The inability to reduce sulfite was confirmed in this study.

$m$ The reported growth range includes temperatures up to $85^{\circ} \mathrm{C}$, but the reported optimum temperature of 60 to $65^{\circ} \mathrm{C}$ suggests that the maximum temperature may be below $85^{\circ} \mathrm{C}$

${ }^{n}$ The $\mathrm{G}+\mathrm{C}$ content was $56 \mathrm{~mol} \%$ when it was determined chemically, but it was 58 mol\% when it was determined by the thermal melting point method.

supplemented with $18 \mathrm{~g}$ of purified agar per liter were used for isolation of the Thorn Hill strains.

The $\mathrm{pHs}$ of some of the culture media were adjusted to values other than 7.2 The medium $\mathrm{pH}$ was adjusted to values between 6.8 and 8.0 by changing the $\mathrm{CO}_{2}$ content of the gas (the balance of the gas was $\mathrm{N}_{2}$ ). MSA media with $\mathrm{pH}$ values higher than 8.0 were obtained by equilibrating with a gas phase consisting of pure $\mathrm{N}_{2}$ and adjusting the $\mathrm{pH}$ by adding $\mathrm{Na}_{2} \mathrm{CO}_{3}$. MSA media with $\mathrm{pH}$ values below 6.8 were obtained by equilibrating with pure $\mathrm{CO}_{2}$ and adjusting the $\mathrm{pH}$ by adding $\mathrm{HCl}$.

Measurement of growth. Growth rates of cultures in MSA medium were calculated from the increases in optical density at $600 \mathrm{~nm}$ of the cultures. The specific growth rates $(\mu)$ were estimated by using the software package TableCurve 2D, version 2.00 (AISN Software, Inc.), to determine the least-squares fit of the Gompertz equation $(18,51)$ to the increase in optical density versus time. The optimum temperature was determined by a least-squares fit of the square root equation (40) to the $\mu$ measured at various temperatures. This equation describes the relationship between $\mu$ and temperature, predicting $\mu=0$ at the minimum and maximum temperatures and positive values for $\mu$ in between (see Fig. 1). Although the equation predicts $\mu=0$ at the maximum growth temperature, it incorrectly predicts $\mu>0$ at temperatures above the maximum temperature $(50)$, so we modified the equation by stipulating $\mu=0$ at temperatures above the maximum temperature.

Physiological and morphological tests. The range of electron donors for sulfate reduction was determined by inoculating cultures into MSA medium containing a potential electron donor at a concentration of $20 \mathrm{mM}$ (or $50 \mathrm{kPa}$ of $\mathrm{H}_{2}$ ), $20 \mathrm{mM}$ sulfate as the electron acceptor, and $0.5 \mathrm{mM} \mathrm{FeSO}_{4} \cdot 7 \mathrm{H}_{2} \mathrm{O}$. The ability of strains to use electron acceptors was determined by inoculating strains into MSA medium containing $20 \mathrm{mM}$ lactate plus a potential electron acceptor at a concentration of $10 \mathrm{mM}$. For the insoluble electron acceptors ferric hydroxide, $\mathrm{MnO}_{2}$, and sulfur, $10 \mathrm{mmol} /$ liter was added (6). Growth was monitored by measuring absorbance and was compared to the growth of controls. Growth of cultures on insoluble substrates was monitored in two ways. Visual comparison with uninoculated controls allowed detection of the depletion of insoluble substrates, such as $\mathrm{MnO}_{2}$ and sulfur, which cause turbidity in media unless they are reduced (to sulfide and manganous ion, respectively). In the case of ferric hydroxide, reduction is accompanied by changes in appearance and precipitation of siderite. Results determined in this way were confirmed by microscopically examining the cultures (to detect increased microbial numbers compared with inoculated control cultures that lacked lactate). Gram staining was performed by the Hucker method (13).
Lipid analysis. Lyophilized cell material $(50 \mathrm{mg})$ was suspended in $142.5 \mathrm{ml}$ of buffered solvent (chloroform-methanol-phosphate buffer [pH 7.4], 1:2:0.8 [vol $\mathrm{vol} / \mathrm{vol}]$ ) (49), sonicated for $2 \mathrm{~min}$, and extracted for $3 \mathrm{~h}$, with mixing once each hour. Chloroform $(37.5 \mathrm{ml})$ and deionized water $(37.5 \mathrm{ml})$ were added, and the mixture was then vigorously shaken and stored overnight. The lower phase was removed, placed into a clean test tube, dried under a stream of $\mathrm{N}_{2}$, and redissolved in a minimal volume of chloroform. This solution was placed on a silicic acid column, and neutral lipids, glycolipids, and polar lipids were eluted with chloroform, acetone, and methanol, respectively (49). The polar lipids were collected, converted to methyl esters (49), separated by gas chromatography with a model HP5890-II gas chromatograph (Hewlett-Packard) equipped with a type HP-1 column ( $50 \mathrm{~m}$ by $0.2 \mathrm{~mm}$ [inside diameter]), and detected with a mode HP5971 mass selective detector (Hewlett-Packard) by using EI + ionization at 70 eV $(35,41)$

A principal-component analysis of the polar lipid fatty acids was performed by using arcsin-transformed moles percent values and the software package Ein*Sight (version 3.0) (InfoMetrix, Inc., Seattle, Wash.).

Analytical methods. Sulfide was measured by the methylene blue method (45) and acetate was measured by gas chromatography (3).

Phylogenetic analysis of rDNA sequences. Cells of strain SLT ${ }^{\mathrm{T}}$ were grown as described previously (24). Genomic DNA was extracted, and 16S ribosomal DNA (rDNA) genes were amplified by $\operatorname{PCR}(38,39)$. Purified PCR products were sequenced with a Taq DyeDeoxy terminator cycle sequencing kit (Applied Biosystems, Foster City, Calif.). The sequence reaction mixtures were analyzed with an Applied Biosystems model 373A DNA sequencer.

DNAs were isolated from the Thorn Hill strains by the chloroform-isoamyl alcohol procedure (22). Approximately $20 \mathrm{ng}$ of DNA was used as a template for PCR amplification (42) of a 1,362-bp continuous rDNA sequence corresponding to Escherichia coli positions 14 to 1397 . The PCR amplification primers (48) used were fD1 (AGAGTTTGATCCTGGCTCAG) and rP2 (ACGGCTACCTTGTT ACGACTT). The PCR amplification products were sequenced with an Applied Biosystems model 373A DNA sequencer by using the Taq DyeDeoxy terminator cycle sequencing method $(1,32)$. The following primers were used for sequencing: C (ACGGGCGGTGTGTAC) (29), corresponding to positions 1406 to 1392 in the $16 \mathrm{~S}$ rDNA nucleotide sequence of $E$. coli (8); C-complement (GTACAC ACCGCCCGT; $E$. coli positions 1392 to 1406); H (ACACGAGCTGACGACA GCCA; positions 1075 to 1056); G (CCAGGGTATCTAATCCTGTT; positions 800 to 781 ); G-complement (AACAGGATTAGATACCCTGG; positions 781 to 800); A (GTATTACCGCGG[C/G]TGCTG; positions 536 to 519); P (CTGCT GCCTCCCGTAGGAG; positions 357 to 339); P-complement (CTACGGGAG 
TABLE 1-Continued

\begin{tabular}{|c|c|c|c|c|c|c|c|c|c|c|c|c|c|c|c|c|}
\hline \multicolumn{11}{|c|}{ Utilization of electron donors with sulfate as the electron acceptor } & \multicolumn{4}{|c|}{$\begin{array}{l}\text { Growth in the absence of } \\
\text { sulfate with: }\end{array}$} & \multicolumn{2}{|c|}{$\begin{array}{l}\text { Utilization of } \\
\text { electron } \\
\text { acceptors }\end{array}$} \\
\hline $\mathrm{H}_{2}$ & mate & Lactate & $\begin{array}{l}\text { Pyru- } \\
\text { vate }\end{array}$ & $\begin{array}{l}\text { Eth- } \\
\text { anol }\end{array}$ & Malate & $\begin{array}{l}\text { Meth- } \\
\text { anol }\end{array}$ & Acetate & $\begin{array}{l}\text { Propio- } \\
\text { nate }\end{array}$ & $\begin{array}{c}\mathrm{Bu}- \\
\text { tyrate }^{a}\end{array}$ & Glucose & Glucose & Fructose & $\begin{array}{l}\text { Pyru- } \\
\text { vate }\end{array}$ & Lactate & $\begin{array}{l}\text { Thio- } \\
\text { sulfate }\end{array}$ & Sulfite \\
\hline+ & + & + & + & + & - & $+(w)$ & - & - & - & - & - & - & + & - & + & + \\
\hline+ & $++^{3}$ & + & + & + & - & $-h$ & - & - & - & - & - & + & + & - & + & $-i$ \\
\hline ND & + & + & + & + & ND & - & - & - & - & - & - & - & ND & ND & ND & ND \\
\hline+ & + & + & + & + & - & $-{ }^{h}$ & - & ND & ND & - & - & - & + & + & + & $-l$ \\
\hline+ & - & + & + & + & - & - & + & - & - & - & - & ND & + & + & ND & ND \\
\hline+ & + & + & + & + & + & - & - & + & + & - & - & - & + & + & + & + \\
\hline+ & + & + & + & + & ND & ND & - & + & + & - & - & + & ND & ND & + & ND \\
\hline+ & $+\left(w^{\prime}\right)$ & + & + & - & + & ND & + & + & + & - & - & ND & + & - & + & - \\
\hline+ & + & + & + & + & + & + & - & - & + & - & - & - & + & + & + & + \\
\hline+ & + & + & + & + & + & + & + & + & + & - & - & - & + & ND & + & + \\
\hline+ & - & + & + & + & ND & - & - & + & + & ND & ND & - & + & ND & + & + \\
\hline
\end{tabular}

GCAGCA(; positions 342 to 357); and $\mathrm{F}_{2} \mathrm{C}$ (AGAGTTTGATC[A/C]TGGCT C; positions 8 to 25 ).

The assembled 16S rDNA sequences of the Thorn Hill strains and strain SLT were hand aligned with the equivalent 16S rDNA or rRNA sequences of all closely related strains found in the GenBank database. The initial sets of prealigned eubacterial sequences were obtained from the Ribosomal Database Project (30), available via the Ribosomal Database Project e-mail server, version 5.0, updated 25 May 1995. Each set of aligned sequences was analyzed for maximum parsimony with the program Phylogenetic Analysis Using Parsimony (43) to construct the most parsimonious phylogenetic tree. Only the phylogenetically informative sites were considered, and alignment gaps were retained in the analysis. A heuristic search was carried out first (with standard program defaults), after which a bootstrap analysis placed confidence limits on the branch points of the resulting phylogenetic trees. Consensus phylogenetic trees for each alignment set were produced by bootstrapping at the greater-than-50\% confidence limit, with 100 replications (16).

The phylogenetic positions of the Thorn Hill strains and strain SLT ${ }^{\mathrm{T}}$, inferred from their 16S rDNA sequences, were compared to the positions of the most closely related organisms, with successive comparisons based on the analytical results of the previous alignment. The analysis indicated that all seven strains were most closely related to species of the genus Desulfotomaculum.

The aligned sequences were then analyzed with parsimony and distance matrix methods. The parsimony analysis was performed with the program Phylogenetic Analysis Using Parsimony as described above. The distance matrix analysis was carried out by using the PHYLIP package of microcomputer programs (16). Distances were calculated by the method of Jukes and Cantor (23), after which phylogenies were estimated with the FITCH option, which makes use of the Fitch-Margoliash criterion (17) and some related least-squares criteria.

\section{RESULTS AND DISCUSSION}

Isolation of strains. The isolation of strain $\mathrm{SLT}^{\mathrm{T}}$ has been described previously (24). Sulfate-reducing bacteria from the deep subsurface were enriched from rock samples obtained at a depth of $2.7 \mathrm{~km}$ below the ground surface. Enrichment cultures were prepared by inoculating small pieces of rock (50 $\mathrm{mg}$ ) into medium $\mathrm{B}$ adjusted to one of three $\mathrm{pH}$ values ( $\mathrm{pH} 7.2$, 8.2, and 9.2) and then incubating the cultures at $50^{\circ} \mathrm{C}$. The enrichment cultures at $\mathrm{pH} 7.2$ and 8.2 grew and produced a visible black precipitate within 30 days, but the culture at $\mathrm{pH}$ 9.2 did not grow. The growing cultures were diluted and inoculated into roll tube media for isolation. After incubation, colonies were picked and reinoculated into roll tube media for purification. The resulting isolates were deposited in the SMCC. The following four pure cultures of sulfate-reducing bacteria were isolated from the culture at $\mathrm{pH}$ 7.2: strains $\mathrm{TH}-$ $11^{\mathrm{T}}$ (= SMCC W459 $9^{\mathrm{T}}$, TH-12 (= SMCC W460), TH-13 (= SMCC W461), and TH-14 (= SMCC W462). Two cultures, strains TH-15 (= SMCC W463) and TH-16 (= SMCC W464), were isolated from the enrichment culture at $\mathrm{pH}$ 8.2. These six strains are referred to collectively as the Thorn Hill strains.
Morphology. The morphology of strain $\operatorname{SLT}^{\mathrm{T}}$ (Table 1) has been described previously (24). The cells of the Thorn Hill strains were rods that were 1 to $1.1 \mu \mathrm{m}$ wide and 2 to $5 \mu \mathrm{m}$ long. The Gram stain results were negative; most other Desulfotomaculum species are gram negative, but all Desulfotomaculum strains that have been examined by electron microscopy have a typical gram-positive cell wall morphology (Table 1). Endospores were observed in malachite green-stained preparations and by phase-contrast microscopy; the endospores were oval and paracentral. No gas vacuoles were observed. Motility was obvious in wet mounts that were warmed to about $50^{\circ} \mathrm{C}$.

Catabolic substrates. All of the Thorn Hill strains grew by oxidizing lactate stoichiometrically to acetate while they reduced sulfate to sulfide. In the presence of sulfate as an electron acceptor, these organisms also grew by oxidizing formate, $\mathrm{H}_{2}$, or pyruvate. Methanol was used weakly (only a small increase in turbidity was observed), but growth was slightly stronger when the concentrations of peptones and yeast extract (normally $2 \mathrm{~g} /$ liter) were reduced to $0.5 \mathrm{~g} /$ liter. We tested methanol catabolism by strain $\mathrm{SLT}^{\mathrm{T}}$ and Desulfotomaculum nigrificans under these conditions, and neither organism catabolized this compound (as reported previously [9]). None of the Thorn Hill strains grew by using acetate, propionate, butyrate, glucose, malate, succinate, or Casamino Acids when sulfate was present as the electron acceptor (Table 1). Strain $\mathrm{TH}-11^{\mathbf{T}}$ did not use caproate, crotonate, or benzoate as an electron donor for sulfate reduction (the other Thorn Hill strains were not tested). All of the Thorn Hill strains also grew by oxidizing lactate and reducing thiosulfate or sulfite, but these organisms did not grow by reducing nitrate, $\mathrm{MnO}_{2}$, or ferric hydroxide. Although strain $\mathrm{SLT}^{\mathbf{T}}$ is reportedly unable to grow by using sulfite as an electron acceptor, we found that it could reduce sulfite (Table 1). The Thorn Hill strains grew on pyruvate, but not on lactate, glucose, or fructose in the presence of $\mathrm{CO}_{2}$ as the only potential electron acceptor.

Physiology. All six Thorn Hill strains were thermophilic, growing at 40 and $60^{\circ} \mathrm{C}$ but not at 35 or $70^{\circ} \mathrm{C}$. Some strains could grow at $65^{\circ} \mathrm{C}$. The estimated temperature range of strain $\mathrm{TH}-11^{\mathrm{T}}$, as determined by fitting the square root equation (40) to $\mu$ at various temperatures, was 22 to $65^{\circ} \mathrm{C}$, and the most rapid growth was estimated to occur at $64^{\circ} \mathrm{C}$ (Fig. 1).

Strain TH- $11^{\mathrm{T}}$ grew fastest at pH 7.0 to 7.9 (Fig. 2), as did $D$. nigrificans and strain $\mathrm{SLT}^{\mathrm{T}}$. The $\mathrm{pH}$ range for growth of each of these organisms is shown in Table 1.

All of the Thorn Hill strains grew in MSA mineral medium 
TABLE 1-Continued

Minimum temp

$\left({ }^{\circ} \mathrm{C}\right)$
Maximum temp

$\left({ }^{\circ} \mathrm{C}\right)$
$\underset{\mathrm{pH}}{\operatorname{Minimum}}$ $\underset{\mathrm{pH}}{\operatorname{Maximum}}$ $\underset{(\% \circ)}{\operatorname{Maximum} \text { salinity }}$

Reference(s)

Deep terrestrial rock

Freshwater

Ovine rumen

Hot spring sediments

Geothermal groundwater

Anaerobic digestor

Geothermal groundwater

Anaerobic digestor

Compost

Hot spring

Deep submarine groundwater

$\begin{array}{cc}<50 & 60-65^{d} \\ <30 & >70 \\ <30 & >48 \\ <50 & >70 \\ <40 & >74 \\ <40 & >70 \\ 37-44 & 54-57 \\ 45-50 & 60-65 \\ <35 & >60 \\ <50 & >85^{m} \\ 37-41 & 75-77\end{array}$

$7.9-8.4$
$7.9-8.0^{j}$
ND
$7.8-8.3^{j}$
$>8.5$
$>8$
$7.8-8.2$
$>7.5$
$>7.5$
$\mathrm{ND}$
$>8.9$

$\begin{array}{cl}10-20 & \text { This study } \\ 10-20 & 9,20,25 \\ \text { ND } & 9,11,20,25 \\ 10-20 & 24 \\ \text { ND } & 31 \\ \text { ND } & 44 \\ >50 & 11 \\ 15-20 & 33 \\ 35 & 15 \\ >30 & 34 \\ 45-50 & 35\end{array}$

containing $\mathrm{H}_{2}$ plus sulfate as the catabolic substrate (after four sequential transfers with $2 \%$ inocula). Calcium was required for growth, and the growth of strain $\mathrm{TH}-11^{\mathrm{T}}$ was completely inhibited by the presence of $2 \% \mathrm{NaCl}$.

These physiological characteristics are consistent with survival and growth of the Thorn Hill strains in their habitat, although it is impossible to know how long these organisms may be able to survive in such an environment. It is possible that these sulfate-reducing bacteria, like Bacillus infernus, which was isolated from the same environment (6), grow vegetatively in rock until their substrates are exhausted and then survive for long periods of time as endospores while local substrates are replenished by diffusion from surrounding rock.

Membrane lipids. The phospholipid fatty acid profiles of the six subsurface isolates are shown in Table 2. The lipids in these organisms are characteristic of the fatty acids of the sulfatereducing bacteria in general $(27,35,41)$ and of the genus Desulfotomaculum in particular. The characteristic fatty acids include terminally methyl-branched saturated fatty acids with the iso configuration predominating (27) and terminally methyl-branched monounsaturated fatty acids, such as i17:1 $\omega 7 \mathrm{c}(27$, 46). The proposed similarity between the subsurface isolates and the genus Desulfotomaculum was illustrated by the results of the principal-component analysis of the phospholipid profiles of the subsurface strains and 23 surface isolates of sulfatereducing bacteria (Fig. 3). Phospholipid profile similarities often reflect phylogenetic similarities as measured by $16 \mathrm{~S}$ rRNA similarities (26), and the profiles indicate that there are similarities between the surface and subsurface strains. However, the Thorn Hill strains lacked detectable 10me16:0 fatty acid,

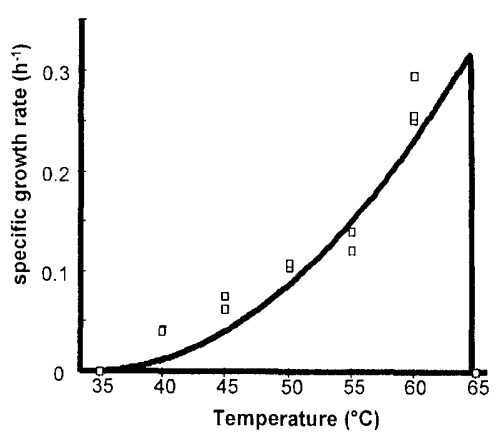

FIG. 1. Effect of temperature on $\mu$ of strain $\mathrm{TH}-11^{\mathrm{T}}$. The points are measured values, and the line is the best fit of the square root equation (40). although this acid was present in $D$. nigrificans (Table 2). This acid has been described as a biomarker for the genus Desulfobacter (26), although it is also present in Desulfovibrio, Desulfobacterium, and Geobacter species (26). The profiles of the subsurface strains were also distinguished from the profiles of surface Desulfotomaculum strains by the presence of terminally

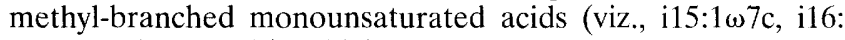
$1 \omega 8 \mathrm{c}$, and $i 16: 1 \omega 6 \mathrm{c})$, which are common to a number of sulfate-reducing bacteria $(14,26,46)$.

Guanine-plus-cytosine content. The DNA of strain $\mathrm{TH}-11^{\mathrm{T}}$ had a guanine-plus-cytosine content of $47.1 \pm 0.7 \mathrm{~mol} \%$; the other Thorn Hill strains had DNA guanine-plus-cytosine contents of 46.5 to $47.6 \mathrm{~mol} \%$.

Phylogenetic analysis of $16 \mathrm{~S}$ rRNA sequences. On the basis of $16 \mathrm{~S}$ rRNA and rDNA sequences, strain TH-11 ${ }^{\mathrm{T}}$ was most similar to D. nigrificans and Desulfotomaculum ruminis (Fig. 4), and strain $\mathrm{SLT}^{\mathrm{T}}$ was most similar to Desulfotomaculum australicum and Desulfotomaculum thermobenzoicum.

Taxonomic analysis. The results of phylogenetic analyses clearly indicated that strains $\mathrm{TH}-11^{\mathbf{T}}$ and $\mathrm{SLT}^{\mathbf{T}}$ are members of the genus Desulfotomaculum. Strains TH- $11^{\mathrm{T}}$ and $\mathrm{SLT}^{\mathrm{T}}$ are also clearly distinguished phylogenetically from each other and from the most closely related members of the genus for which sequences are available, with the closest relatives exhibiting about $95 \%$ sequence similarity. Levels of sequence similarity of $<98 \%$ indicate that the phylogenetic distance is great enough for placement in a separate species $(7,12)$, and establishment of a new species should require phenotypic as well as phylogenetic differences (47).

Taxonomy of strain TH-11 ${ }^{\mathbf{T}}$. Table 1 shows phenotypic characteristics of strains $\mathrm{TH}-11^{\mathrm{T}}$ and $\mathrm{SLT}^{\mathrm{T}}$, previously described

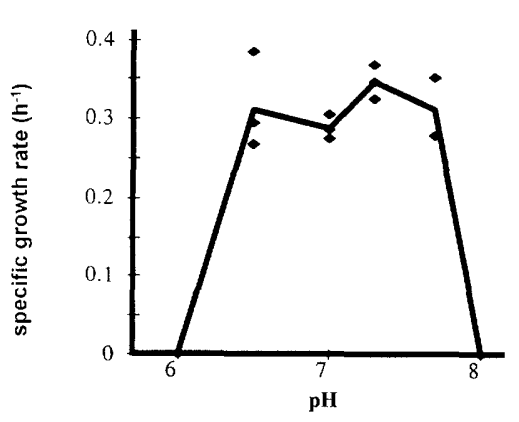

FIG. 2. Effect of $\mathrm{pH}$ on $\mu$ of strain $\mathrm{TH}-11^{\mathrm{T}}$. 
TABLE 2. Levels of individual polar lipid fatty acids in the Thorn Hill strains and $D$. nigrificans

\begin{tabular}{|c|c|c|c|c|c|c|c|}
\hline \multirow{2}{*}{$\begin{array}{l}\text { Fatty } \\
\text { acid }\end{array}$} & \multicolumn{7}{|c|}{ mol\% in: } \\
\hline & $\mathrm{TH}-11^{\mathrm{T}}$ & TH-12 & TH-13 & TH-14 & TH-15 & TH-16 & D. nigrificans ${ }^{a}$ \\
\hline i14:0 & 0.5 & 0.8 & 0.7 & 0.9 & 1.1 & 0.8 & 0.0 \\
\hline 14:0 & 8.8 & 11.6 & 10.8 & 10.9 & 11.1 & 9.4 & 2.0 \\
\hline i $15: 1 \omega 7 \mathrm{c}$ & 2.2 & 2.9 & 2.4 & 3.2 & 3.2 & 2.6 & 0.0 \\
\hline i15:0 & 15.4 & 16.6 & 18.3 & 19.5 & 21.9 & 19.7 & 8.0 \\
\hline a15:0 & 1.6 & 1.6 & 1.8 & 1.4 & 1.8 & 1.7 & 4.0 \\
\hline 15:0 & 3.3 & 2.4 & 2.4 & 1.8 & 1.9 & 2.0 & 0.0 \\
\hline i16:1 $1 \omega 8 \mathrm{c}$ & 0.7 & 0.8 & 0.8 & 0.9 & 0.9 & 0.9 & 0.0 \\
\hline 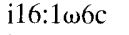 & 1.5 & 1.5 & 1.6 & 1.6 & 1.6 & 1.7 & 0.0 \\
\hline i16:0 & 1.8 & 1.7 & 2.1 & 2.1 & 2.1 & 2.5 & 1.0 \\
\hline $16: 1 \omega 9 c$ & 4.4 & 4.6 & 4.0 & 4.1 & 3.7 & 3.9 & 0.0 \\
\hline $16: 1 \omega 7 \mathrm{c}$ & 13.3 & 13.5 & 11.6 & 12.0 & 10.6 & 11.4 & 5.0 \\
\hline $16: 1 \omega 5 \mathrm{c}$ & 0.9 & 1.0 & 0.8 & 0.9 & 0.7 & 0.7 & 0.0 \\
\hline $16: 0$ & 20.7 & 18.8 & 19.3 & 18.3 & 16.6 & 18.4 & 28.0 \\
\hline i17:1 $1 \omega 9 \mathrm{c}$ & 1.2 & 1.2 & 1.2 & 1.2 & 1.2 & 1.2 & 0.0 \\
\hline $\mathrm{i} 17: 1 \omega 7 \mathrm{c}$ & 12.1 & 11.1 & 11.4 & 10.7 & 11.2 & 11.8 & 11.0 \\
\hline 10Me16:0 & 0.0 & 0.0 & 0.0 & 0.0 & 0.0 & 0.0 & 3.0 \\
\hline $\mathrm{a} 17: 1 \omega 7 \mathrm{c}$ & 0.5 & 0.0 & 0.4 & 0.5 & 0.4 & 0.5 & 1.0 \\
\hline i17:0 & 5.2 & 4.6 & 5.0 & 4.2 & 4.9 & 5.9 & 14.0 \\
\hline a17:0 & 0.5 & 0.4 & 0.4 & 0.3 & 0.3 & 0.4 & 6.0 \\
\hline 17:0 & 0.3 & 0.2 & 0.2 & 0.2 & 0.2 & 0.2 & 1.0 \\
\hline $18: 1 \omega 9 \mathrm{c}$ & 0.4 & 0.3 & 0.3 & 0.2 & 0.2 & 0.3 & 2.0 \\
\hline $18: 1 \omega 7 \mathrm{c}$ & 0.8 & 0.7 & 0.7 & 0.6 & 0.5 & 0.7 & 3.0 \\
\hline 18:0 & 1.0 & 0.6 & 0.8 & 1.2 & 1.3 & 0.6 & 2.0 \\
\hline Other & 2.8 & 3.1 & 2.9 & 3.1 & 2.6 & 2.6 & 9.0 \\
\hline Total & 100.0 & 100.0 & 100.0 & 100.0 & 100.0 & 100.0 & 100.0 \\
\hline
\end{tabular}

${ }^{a}$ Data from reference 28.

b Fatty acids that account for $<0.75 \mathrm{~mol} \%$ of the total fatty acids.

thermophilic Desulfotomaculum species, and the mesophilic species D. ruminis. D. ruminis is included because it (as well as $D$. nigrificans) exhibited a close phylogenetic relationship to strain $\mathrm{TH}-11^{\mathrm{T}}$. We believe that strain $\mathrm{TH}-11^{\mathrm{T}}$ is sufficiently phenotypically different from $D$. ruminis and $D$. nigrificans to justify its placement in a new species. The difference in temperature range alone is sufficient to distinguish $\mathrm{TH}-11^{\mathrm{T}}$ from D. ruminis, and there are other phenotypic differences, such as cell width, methanol utilization, and the ability to grow without acetate (Table 1). Strain $\mathrm{TH}-11^{\mathrm{T}}$ differs from $D$. nigrificans in the following ways: cells of $\mathrm{TH}-1^{\mathrm{T}}$ are much wider than $D$. nigrificans cells; $\mathrm{TH}-11^{\mathrm{T}}$ uses sulfite as an electron acceptor; $\mathrm{TH}-11^{\mathrm{T}}$ uses methanol as an electron donor; $\mathrm{TH}-11^{\mathrm{T}}$ grows without any growth factors; and $\mathrm{TH}-11^{\mathrm{T}}$ has a lower maximum temperature than D. nigrificans (Table 1). Therefore, below we propose a new Desulfotomaculum species with strain TH-11 as the type strain.

Description of Desulfotomaculum putei. Desulfotomaculum putei (pu'te.i. L. gen. n. putei, of a pit or well, referring to the source of the type strain, an exploratory gas well). Cells are motile rods that are 1 to 1.1 by 2 to $5 \mu \mathrm{m}$. Endospores are paracentral and oval. Strictly anaerobic. Thermophilic. Growth occurs at $\mathrm{pH} 6$ to 7.8. Growth is respiratory with formate, $\mathrm{H}_{2}$, pyruvate, ethanol, methanol, or lactate as the electron donor and sulfate, thiosulfate, or sulfite as the electron donor. Acetate, malate, and glucose are not catabolized, either alone or in the presence of sulfate, and sulfur is not reduced. Growth occurs on fructose or on pyruvate in the absence of an electron acceptor other than $\mathrm{CO}_{2}$, but no growth occurs on glucose. The habitat is the deep terrestrial subsurface. The type strain is TH-11 (= SMCC W459), and the reference strains include strains TH-12, TH-13, TH-14, TH-15, and TH-16.

Taxonomy of strain SLT $^{\mathrm{T}}$. Strain $\mathrm{SLT}^{\mathrm{T}}$ is phylogenetically most similar to $D$. australicum and D. thermobenzoicum (Fig. 4). Strain SLT $^{\mathbf{T}}$ differs from $D$. australicum by using formate but not acetate as an electron donor and growing only in a narrower range of $\mathrm{pH}$ values. Strain $\mathrm{SLT}^{\mathrm{T}}$ differs from $D$. thermobenzoicum by having narrower cells, by not reducing sulfite, by not using malate as an electron donor, and by not requiring yeast extract for growth. We therefore propose the new species described below.

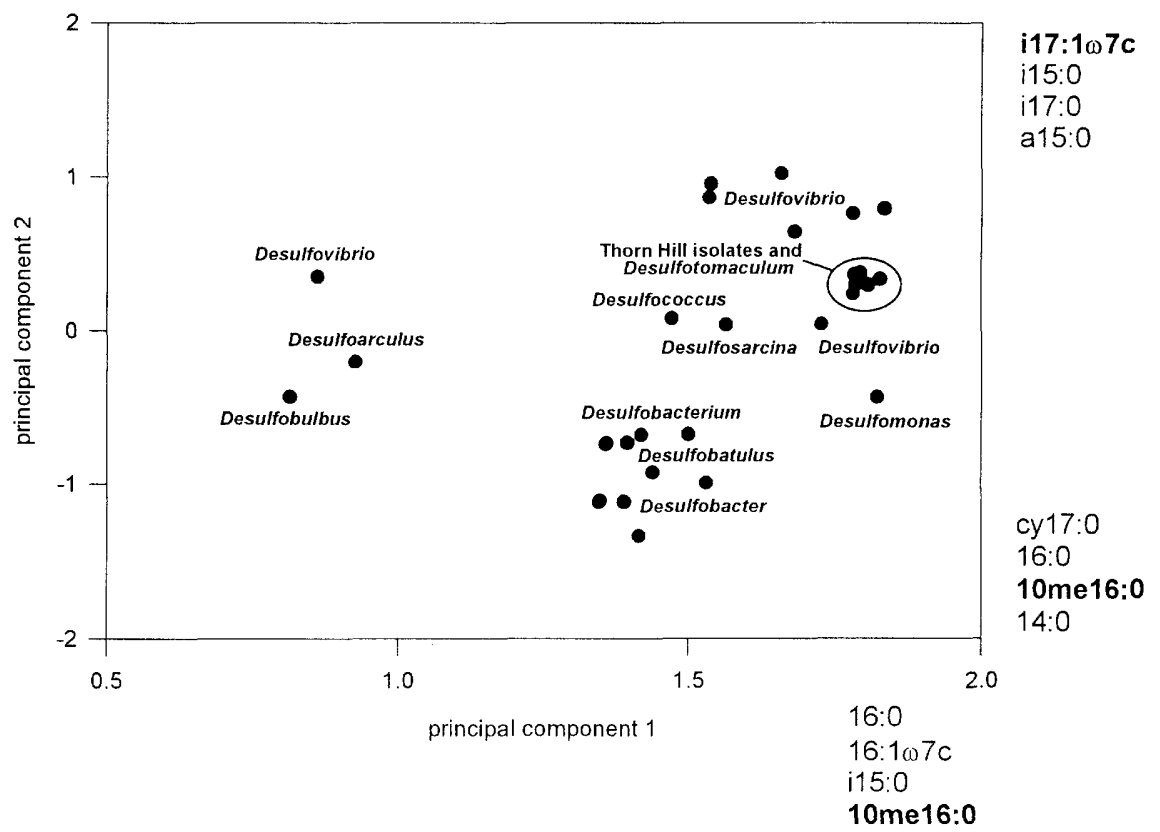

FIG. 3. Principal-component analysis of the fatty acids of membrane lipids of sulfate-reducing bacteria (26), including D. nigrificans and the Thorn Hill isolates. The arcsin-transformed moles percent values of the fatty acids were analyzed. Principal component 1 is labeled with the four variables assigned the greatest coefficient of loading, and principal component 2 is the four greatest positive and negative coefficients (indicated by fatty acid designations to the right of and below the figure). The phospholipid fatty acids which are indicative of sulfate-reducing bacteria are indicated in boldface type. 


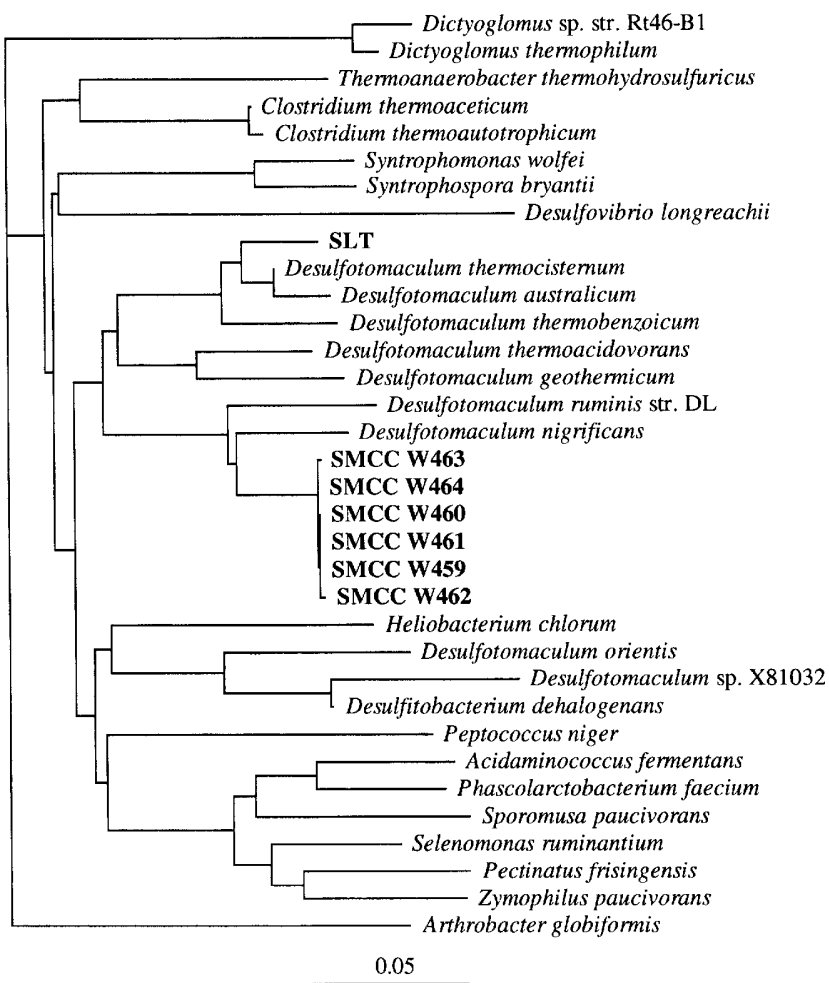

FIG. 4. Phylogenetic tree for strain SLT', the six Thorn Hill strains, and selected species of eubacteria, based on the results of a distance matrix analysis Arthrobacter globiformis was used as the outgroup. Scale bar $=5$ substitutions per 100 bases. Strain SLT and the subsurface strains were assigned to the same positions (relative to the selected eubacterial species) on the phylogenetic trees produced by parsimony and maximum-likelihood analysis methods (data not shown).

Description of Desulfotomaculum luciae. Desulfotomaculum luciae (lu'ci.ae. L. gen. n. luciae of Lucia, referring to the source of the type strain, a hot spring in St. Lucia). Cells are motile rods that are 1 by $3 \mu \mathrm{m}$. Endospores are central and spherical. Strictly anaerobic. Thermophilic. Growth occurs at $\mathrm{pH} 6.3$ to 7.8 . Growth is respiratory with formate, $\mathrm{H}_{2}$, pyruvate, ethanol, or lactate as the electron donor and sulfate or thiosulfate as the electron donor. Acetate, malate, methanol, and glucose are not catabolized, either alone or in the presence of sulfate, and sulfur and sulfite are not reduced. Growth occurs on pyruvate or lactate in the absence of an electron acceptor other than $\mathrm{CO}_{2}$, but no growth occurs on fructose or glucose. The habitat is hot springs. The type strain is SLT (= SMCC W644).

\section{ACKNOWLEDGMENTS}

We thank William B. Whitman (University of Georgia) for measuring the base content of the DNA, and we thank Ellyn Whitehouse (Florida State University Sequencing Facility) and Priya Kadam (Oregon Graduate Institute) for advice and technical assistance. We thank Peter H. A. Sneath (University of Leicester) for advice on the orthography of the specific epithets.

This research was supported by the U.S. Department of Energy Subsurface Science Program (Deep Microbiology Subprogram) under grant DE-FG05-90ER61039 (to D.L.B. and D.R.B.); by the Pacific Northwest National Laboratory through master agreement 206010-AL2, task order no. 258705 (to D.R.B.); by Martin Marietta contract DE-AC05-84OR21400, subcontract 19K-SN985C (to D.R.B.); by the Partners in Science Program sponsored by the Murdock Charitable Trust (D.R.B.); and by the Natural Sciences and Engineering Research
Council of Canada (K.F.J.). Pacific Northwest National Laboratory is operated for the U.S. Department of Energy by Battelle Memorial Institute under contract DE-AC06-76RLO-1830.

\section{REFERENCES}

1. Applied Biosystems, Inc. 1992. Taq DyeDeoxy terminator cycle sequencing kit user bulletin no. 901497, revision E. Applied Biosystems, Inc., Foster City, Calif.

2. Balkwill, D. L., D. R. Boone, F. S. Colwell, T. Griffin, T. L. Kieft, R. M. Lehman, J. P. MkKinley, S. Nierzwickie-Bauer, T. C. Onstott, H. Y. Tseng, G. Gao, T. J. Phelps, D. Ringelberg, B. Russell, T. O. Stevens, D. C. White, and F. J. Wobber. 1994. D.O.E. seeks origin of deep subsurface bacteria. Eos 75:385, 395-396

3. Boone, D. R. 1982. Terminal reactions in the anaerobic digestion of animal waste Appl. Environ. Microbiol. 43:57-64.

4. Boone, D. R., R. L. Johnson, and Y. Liu. 1989. Diffusion of the interspecies electron carriers $\mathrm{H}_{2}$ and formate in methanogenic ecosystems and its implications in the measurement of $K_{m}$ for $\mathrm{H}_{2}$ or formate uptake. Appl. Environ. Microbiol. 55:1735-1741.

5. Boone, D. R., Y. Liu, and T. O. Stevens. 1994. Abstracts of the 94th General Meeting of the American Society for Microbiology 1994, p. 320, abstr. N-25

6. Boone, D. R., Y. Liu, Z. Zhao, D. L. Balkwill, G. R. Drake, T. O. Stevens, and H. C. Aldrich. 1995. Bacillus infernus sp. nov., an Fe(III)- and Mn(IV)reducing anaerobe from the deep terrestrial subsurface. Int. J. Syst. Bacteriol. 45:441-448.

7. Boone, D. R., W. B. Whitman, and P. Rouvière. 1993. Diversity and taxonomy of methanogens, p. 35-80. In J. G. Ferry (ed.), Methanogenesis: ecology, physiology, biochemistry, and genetics. Chapman \& Hall, New York, N.Y.

8. Brosius, J., M. L. Palmer, P. J. Kennedy, and H. R. Noller. 1978. Complete nucleotide sequence of a 16S ribosomal RNA gene from Escherichia coli. Proc. Natl. Acad. Sci. USA 75:4801-4805.

9. Campbell, L. L., and J. R. Postgate. 1965. Classification of the spore-forming sulfate-reducing bacteria. Bacteriol. Rev. 29:359-363.

10. Colwell, F. S., G. J. Stormberg, T. J. Phelps, S. A. Birnbaum, J. McKinley, S. A. Rawson, C. Veverka, S. Goodwin, P. E. Long, B. F. Russell, T. Garland, D. Thompson, P. Skinner, and S. Grover. 1992. Innovative techniques for collection of saturated and unsaturated subsurface basalts and sediments for microbiological characterization. J. Microbiol. Methods 15:279-292.

11. Daumas, S., R. Cord-Ruwisch, and J. L. Garcia. 1988. Desulfotomaculum geothermicum sp. nov., a thermophilic, fatty acid-degrading, sulfate-reducing bacterium isolated with $\mathrm{H}_{2}$ from geothermal ground water. Antonie van Leeuwenhoek 54:165-178.

12. Devereux, R., S. H. He, C. L. Doyle, S. Orkland, D. A. Stahl, J. LeGall, and W. B. Whitman. 1990. Diversity and origin of Desulfovibrio species: phylogenetic definition of a family. J. Bacteriol. 172:3609-3619.

13. Doetsch, R. N. 1981. Determinative methods of light microscopy, p. 21-33. In P. Gerhardt, R. G. E. Murray, R. N. Costilow, E. W. Nester, W. A. Wood N. R. Krieg, and G. B. Phillips (ed.), Manual of methods for general bacteriology. American Society for Microbiology, Washington, D.C

14. Dowling, N. J., F. Widdel, and D. C. White. 1986. Phospholipid ester-linked fatty acid biomarkers of acetate-oxidizing sulphate reducers and other sul phide-forming bacteria. J. Gen. Microbiol. 132:1815-1825.

15. Fardeau, M. L., B. M. Ollivier, B. K. C. Patel, P. Dwivedi, M. Ragot, and J. L. Garcia. 1995. Isolation and characterization of a thermophilic sulfate-reducing bacterium, Desulfotomaculum thermosapovorans sp. nov. Int. J. Syst. Bacteriol. 45:218-221.

16. Felsenstein, J. 1993. PHYLIP (phylogeny inference package), version $3.5 \mathrm{c}$ University of Washington, Seattle.

17. Fitch, W. M., and E. Margoliash. 1967. Construction of phylogenetic trees. Science 155:279-284.

18. Gompertz, B. 1825. On the nature of the function expressive of the law of human mortality and on a new mode of determining the value of life contingencies. Philos. Trans. R. Soc. London 115:513-585.

19. Henry, E. A., R. Devereaux, J. S. Maki, C. C. Gilmour, C. R. Woese, L Mandelco, R. Schauder, C. C. Remsen, and R. Mitchell. 1994. Characterization of a new thermophilic sulfate-reducing bacterium, Thermodesulfovibrio yellowstonii gen. nov. and sp. nov.: its phylogenetic relationship to Thermodesulfobacterium commune and their origins deep within the bacterial domain. Arch. Microbiol. 161:62-69.

20. Holt, J. G., N. R. Krieg, P. H. A. Sneath, J. T. Staley, and S. T. Williams (ed.) 1994. Bergey's manual of determinative bacteriology, 9th ed. Williams \& Wilkins, Baltimore, Md.

21. Hungate, R. E. 1969. A roll tube method for cultivation of strict anaerobes, p. 117-132. In J. R. Norris and D. W. Ribbons (ed.), Methods in microbiology. Academic Press, New York, N.Y.

22. Johnson, J. L. 1981. Genetic characterization, p. 450-472. In P. Gerhardt, R. G. E. Murray, R. N. Costilow, E. W. Nester, W. A. Wood, N. R. Krieg and G. B. Phillips (ed.), Manual of methods for general bacteriology. American Society for Microbiology, Washington, D.C.

23. Jukes, T. H., and C. R. Cantor. 1969. Evolution of protein molecules, p. 21-132. In H. N. Munro (ed.), Mammalian protein metabolism. Academic Press. New York, N.Y. 
24. Karnauchow, T. M., S. F. Koval, and K. F. Jarrell. 1992. Isolation and characterization of 3 thermophilic anaerobes from a St. Lucia hot spring. Syst. Appl. Microbiol. 15:296-310.

25. Klemps, R., H. Cypionka, F. Widdel, and N. Pfennig. 1985. Growth with hydrogen, and further physiological characteristics of Desulfotomaculum species. Arch. Microbiol. 143:203-208.

26. Kohring, G. W., J. E. Rogers, and J. Wiegel. 1989. Anaerobic biodegradation of 2,4-dichlorophenol in freshwater lake sediments at different temperatures. Appl. Environ. Microbiol. 55:348-353.

27. Kohring, G. W., X. M. Zhang, and J. Wiegel. 1989. Anaerobic dechlorination of 2,4-dichlorophenol in freshwater sediments in the presence of sulfate. Appl. Environ. Microbiol. 55:2735-2737.

28. Kohring, L. L., D. B. Ringelberg, R. Devereux, D. Stahl, M. W. Mittleman, and D. C. White. 1994. Comparison of phylogenetic relationships based on phospholipid fatty acid profiles and ribosomal RNA sequence similarities among dissimilatory sulfate-reducing bacteria. FEMS Microbiol. Lett. 119: $303-308$.

29. Lane, D. J., B. Pace, G. J. Olsen, D. A. Stahl, M. L. Sogin, and N. R. Pace. 1985. Rapid determination of 16 S ribosomal RNA sequences for phylogenetic analyses. Proc. Natl. Acad. Sci. USA 82:6955-6959.

30. Larsen, N., J. G. Olsen, B. L. Maidak, M. J. McCaughey, R. Overbeek, T. J. Macke, T. L. Barsh, and C. R. Woese. 1993. The Ribosomal Database Project. Nucleic Acids Res. 21:3021-3023.

31. Love, C. A., B. K. C. Patel, P. D. Nichols, and E. Stackebrandt. 1993. Desulforomaculum australicum, sp. nov., a thermophilic sulfate-reducing bacterium isolated from the Great Artesian Basin of Australia. Syst. Appl. Microbiol. 16:244-251.

32. McBride, L. J., S. M. Koepf, R. A. Gibbs, W. Salser, P. E. Mayrand, M. W. Hunkapiller, and M. N. Kronick. 1989. Automated DNA sequencing methods involving polymerase chain reaction. Clin. Chem. 35:2196-2201.

33. Min, H., and S. H. Zinder. 1990. Isolation and characterization of a thermophilic sulfate-reducing bacterium, Desulfotomaculum thermoacetoxidans sp. nov. Arch. Microbiol. 153:399-404.

34. Nazina, T. N., A. E. Ivanova, L. P. Kanchaveli, and E. P. Rozanova. 1988. A new sporeforming, thermophilic, methylotrophic sulfate-reducing bacterium, Desulforomaculum kuznetsovii. Mikrobiologiya 57:823-827.

35. Nichols. P. D., J. B. Guckert, and D. B. White. 1986. Determination of monounsaturated fatty acid double bond position and geometry for microbial monocultures and complex consortia by capillary GC-MS of their dimethyl disulphide adducts. J. Microbiol. Methods 5:49-55.

36. Nilsen, R. K., T. Torsvik, and T. Lien. 1996. Desulfotomaculum thermocisternum sp. nov., a sulfate reducer isolated from a hot North Sea oil reservoir Int. J. Svst. Bacteriol. 46:397-402.

37. Postgate, J. R. 1984. Genus Desulfovibrio Kluyver and van Niel 1936, $397^{\text {AL }}$, p. 666-672. In N. R. Krieg and J. G. Holt (ed.), Bergey's manual of systematic bacteriology, vol. 1. Williams \& Wilkins, Baltimore, Md.

38. Rainey, F. A., M. Dorsch, H. W. Morgan, and E. Stackebrandt. 1992. 16S
rRNA analysis of Spirochaeta thermophila: position and implications for systematics of the order Spirochaetales. Syst. Appl. Microbiol. 16:224-226.

39. Rainey, F. A. and E. Stackebrandt. 1993. Transfer of the type species of the genus Thermobacteroides to the genus Thermoanaerobacter as Thermoanaerobacter acetoethylicus (Ben-Bassat and Zeikus 1981) comb. nov., description of Coprothermobacter gen nov., and reclassification of Thermobacteroides proteolyticus as Coprothermobacter proteolyticus (Ollivier et al. 1985) comb. nov. Int. J. Syst. Bacteriol. 43:857-859.

40. Ratkowsky, D. A., R. K. Lowry, T. A. McMeekin, A. N. Stokes, and R. E. Chandler. 1983. Model for bacterial culture growth rate throughout the entire biokinetic temperature range. J. Bacteriol. 154:1222-1226.

41. Ringelberg, D. B., G. T. Townsend, K. A. DeWeerd, J. M. Suflita, and D. C White. 1994. Detection of the anaerobic dechlorinating microorganism $D e$ sulfomonile tiedjei in environmental matrices by its signature lipopolysaccharide branched-long-chain hydroxy fatty acids. FEMS Microbiol. Ecol. 14:918.

42. Sambrook, J., E. F. Fritsch, and T. Maniatis. 1989. Molecular cloning, 2nd ed. Cold Spring Harbor Laboratory Press, Cold Spring Harbor, N.Y

43. Swofford, D. L. 1993. PAUP: phylogenetic analysis using parsimony, version 3.1.1. Illinois Natural History Survey, Champaign.

44. Tasaki, M., Y. Kamagata, K. Nakamura, and E. Mikami. 1991. Isolation and characterization of a thermophilic benzoate-degrading, sulfate-reducing bacterium, Desulfotomaculum thermobenzoicum sp. nov. Arch. Microbiol. 155: 348-352.

45. Trüper, H. G., and H. G. Schlegel. 1964. Sulfur metabolism in Thiorhodaceae. I. Quantitative measurements on growing cells of Chromatium okenii. Antonie van Leeuwenhoek J. Microbiol. Serol. 30:225-238.

46. Vainshtein, M., H. Hippe, and R. Kroppenstedt. 1992. Cellular fatty acid composition of Desulfovibrio species and its use in classification of sulfatereducing bacteria. Syst. Appl. Microbiol. 15:554-566.

47. Wayne, L. G., D. J. Brenner, R. R. Colwell, P. A. D. Grimont, O. Kandler, M. I. Krichevsky, L. H. Moore, W. E. C. Moore, R. G. E. Murray, E. Stackebrandt, M. P. Starr, and H. G. Trüper. 1987. Report of the Ad Hoc Committee on Reconciliation of Approaches to Bacterial Systematics. Int. J. Syst. Bacteriol. 37:463-464.

48. Weisburg, W. G., S. M. Barns, D. A. Pelletier, and D. J. Lane. 1991. 16S ribosomal DNA amplification for phylogenetic study. J. Bacteriol. 173:697703

49. White, D. C., W. M. Davis, J. S. Nickels, J. D. King, and R. J. Bobbie. 1979 Determination of the sedimentary microbial biomass by extractable lipid phosphate. Oecologia (Berlin) 40:51-62.

50. Zwietering, M. H., J. T. de Koos, B. E. Hasenack, J. C. de Wit, and K. van't Riet. 1991. Modeling of bacterial growth as a function of temperature. Appl. Environ. Microbiol. 57:1094-1101.

51. Zwietering, M. H., I. Jongenburger, F. M. Rombouts, and K. van't Riet. 1990. Modeling of the bacterial growth curve. Appl. Environ. Microbiol. 56:1875-1881. 